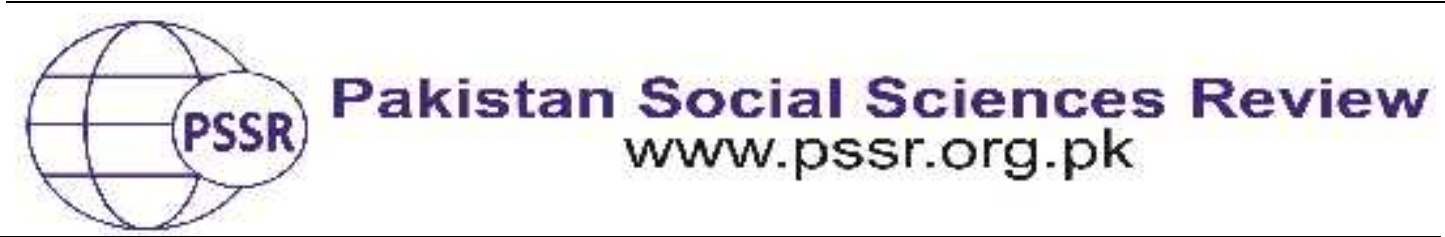

RESEARCH PAPER

\title{
A Textual Enactment of Cartoon and Editorial: CDA and Semiotic Analysis of Daily Dawn Coverage of 89-Year Record Shattering Rains of Karachi
}

Dr. Muhammad Shabbir Sarwar ${ }^{1}$ Muhammad Ahsan Bhatti² Humara Gulzar ${ }^{3}$

1. Assistant Professor, Institute of Communication Studies, University of the Punjab, Lahore, Punjab, Pakistan

2. Assistant Professor, Department of Communication Studies, Bahauddin Zakariya University Multan, Punjab, Pakistan

3. M. Phil, Media Studies, Islamia University Bahawalpur, Punjab, Pakistan

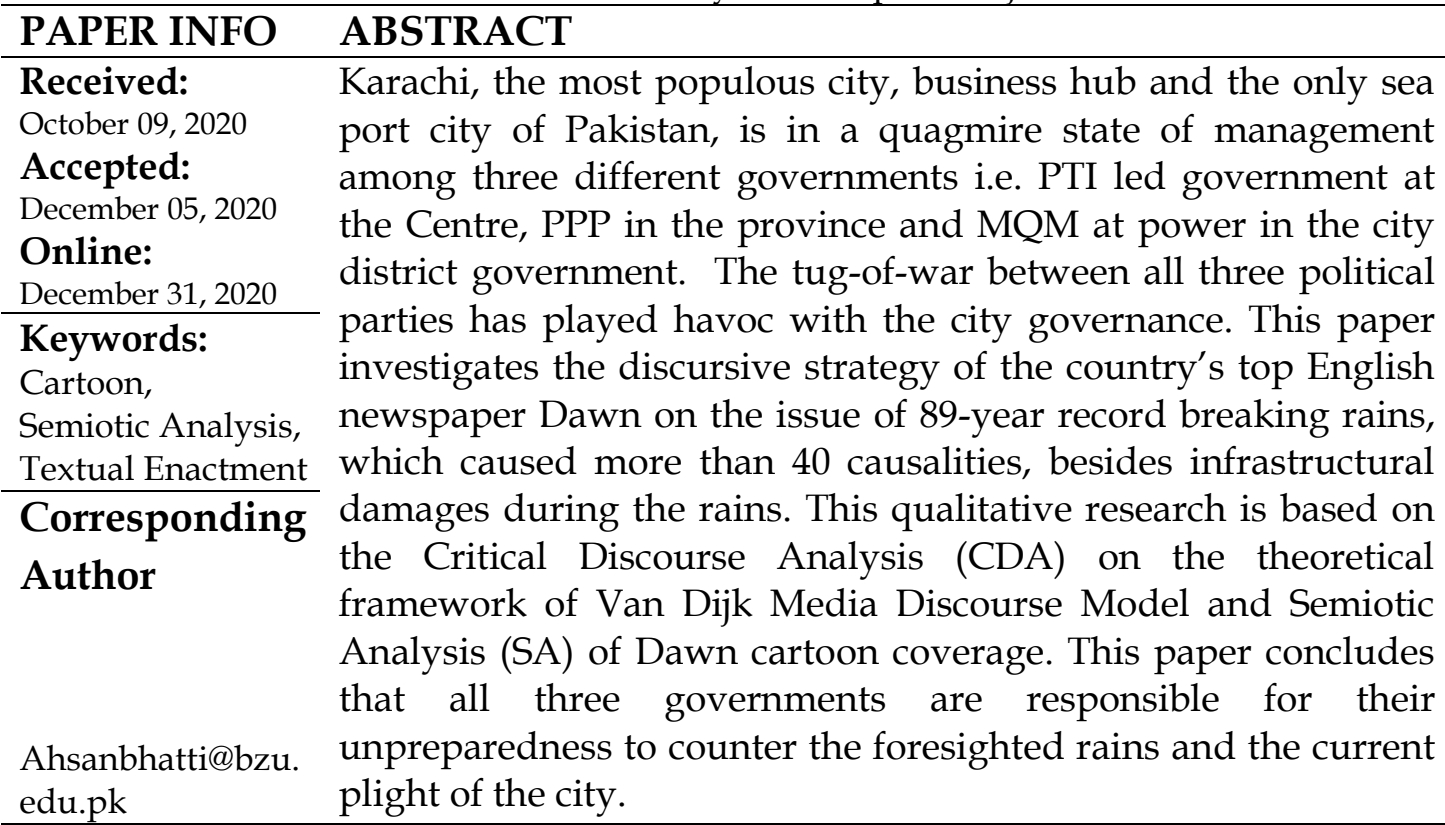

\section{Introduction}

A society is not only damaged by disordered societal values and rituals but also by natural disaster like rainstorms. Catastrophe and media coverage discloses that how political system and rituals are maintained and established. In journalism, many tools like live reports and emotional visualization are symbolically used to heal the traumatized society just after the calamity. So, in disaster journalism, media has top score to play its role to uplift the society (Chiaoning, 2020).

Media sensitize public cognizance and opinion formation other than transformation of the society (Anderson,2007) and update legislators and people on different issues (Hoppe \& Wolling, 2011). Media is considered a best instrument for gaining plentiful information regarding global news issues, current affairs and 
national news (Dearing \& Rogers,1988). Climate change is one of the key issues which are covered by media industry nowadays (Azmi,Omar, Zaid, Wahab, \&Yosuf, 2015).

Media is an important informer about the climate change in terms of knowledge building of the people. In complex and uncertain situations, media shapes the discourse and action of the audiences. General know how about the climate change is explored with help of the media to form a public opinion about the issue (Boykoff\& Roberts,2007).

Communication systems has the potential to perform, from the avoidance and information transmitting to crises cautions, to aid tools and restoration, in torrential floods management cycle. Media bridges between higher authorities and the population of that area. The best remedy in flood disaster is maintaining the good relation between decision makers and communication strategy. Environmental issues especially the flood related issues, expressed by the media, surely help the development of the area destroyed (Ribold et al., 2015).

Climate change a foremost global issue and like the whole globe, Pakistan is facing environmental issues. Print media of Pakistan is representing environmental issues to inform the readers about climate change and its effects. Global warming, smog, air pollution and unprecedented rains are given coverage in the English newspapers of Pakistan (Ali, 2020).

\section{Study Background}

This is a well-acknowledged reality that climate change is becoming sign of danger for many counties. (Anderson, 2009). Pakistan being a populous country, with population of Approx. 22 million, is $7^{\text {th }}$ most targeted country in terms of climate change. Most of the research dissertations are Eurocentric, UK contributed a lot in this connection compared to other European countries, however, very few number of research scholars have paid attention to environment issues in Asian countries (Kamboh \&Yousaf, 2019). The purpose of this article to shed light on the environmental disaster covered by English Print media of Pakistan.

Sindh province has been historically affected by natural and manmade calamities. The calamities suffered by Sindh are from heavy flooding, torrential downpours, shoreline hurricanes, sea disturbance, famines, earthquakes etc. The landscape of Sindh is smooth and horizontal, situated at the lowermost of Indus. Indus River's leftover water has to route through Sindh Province. River Indus part in Sindh is hazardous as it moves at edge, caused high floods in Sindh especially Karachi. Heavy flooding seen since the irrigation system creation in 1932. The years faced heavy rainfalls are1942,1956,1957,1958,1973,1975,1976,1979,1992,1994,1995,2003,2005 and 2007. Total of 411,000 acres of agriculture lands and18,500 kilometers of road structures 
damaged only in 2003 rains. The after effects of Tsunami 2004 created panic situation in shore side population of province specially Karachi (PDMA, 2020).

Karachi, the most populous city of Pakistan with a population of around 15 million people, faced almost a century record breaking heaviest flooding rainfalls in the month of August. The National Disaster Management Agency (NDMA) worried about hundreds of people of slums stuck in water logging. Pakistan Navy reached there to rescue people in trouble (DW, 2020).

Karachi faced record-broken downpours in a single day resulted in 41 people's deaths. This flood was due to dual factors: improper sewerage system and the heavy rains' water. High authorities moved the affected families in school buildings to safeguard them. Pouring rainfalls in Karachi actually shattered 89-year record (Dawn, 2020).

Heavy monsoon rainfalls in Karachi has caused deaths of 50 people. Disastrous rains have damaged one hundred homes, destroying many villages in the province. More than 100 affected people in the flood were rescued by the military in Dadu district (Aljazeera, 2020).

\section{Literature Review}

Media is assumed as the alleviation weapon for management as its linguistic material provides calamity and risk awareness as one-step towards sensitizing the environmental issues to the public. Three players are important in the procedure of efficient disaster management: governmental offices that create calamity information, the media that disseminate the information, the citizens who perceive the awareness and knowledge about disaster and behave in accordance with their culture and situation. Area leadership and some other institutions, having indirect association in disaster situation, are the neglected factors in the disaster management scholarships (Marla, 2001).

Focus on the climatic change news by the print media help enhance the knowledge of public about the environmental issues. Editorial boards of print media should self-realize the social responsibility to report clear and prominent picture of environmental issues in order to upgrade public access and information. To sensitize the climate change issues, purpose-build training sessions of the journalists be arranged to equip them with best textual approaches towards the production of appealing story writing tactics (Siyao\&Sife, 2020).

Greater attention needed for the policies and strategic plans on the issue of climate change to attain climate alleviation and catastrophe readiness. A good national climate policy of the country serves to avoid the disaster in the country. Blame games is the major issue in developing and under developing countries in the way of extreme condition coming out from climate change leading towards the downfall of a nation (Lahsen, Couto\&Lorenzoni, 2020). 
Natural disaster victims behave differently in accordance with traditions, norms, needs and magnitude of damages suffered by the communities. There is a significant relationship with perceptions of community by the people and area of damages incurred. These perceptions are made within the public by proper dissemination of information about the upcoming risks of floods and their preparedness of the disaster (Albright, E.A., Cr \& D, 2019).

\section{Theoretical Support}

This study based on Critical Discourse Analysis (CDA) and Semiotic analysis. Theoretical framework for this study was designed from Van Dijk's (1985) Critical Discourse Analysis (CDA) approach to best examine the Dawn editorial coverage on the disastrous rains in Karachi. CDA is a research approach through which linguistic or non-linguistic texts are investigated to demystify the powers and principles (Fairclough,1995).

CDA has clear social-political phenomena, an approach to unveil the unjust relationships of supremacy and authority and to expose the role of dissertation in the reproduction of sociopolitical power and control (Bell \& Garret, 2001).

According to Bell \& Garret (2001) CDA enables researchers to investigate media discourse within the linguistics and dissertation. Critical discourse allows to investigate powerful authorities in a critical way (Aidoo, 2000).

For the study of cartoon, the researcher selected semiotic analysis as tool for methodology. Semiotic, also known as semiotic study is the scholarship of any act, procedure or motion that is derived from a sign, which conveys a meaning.Semiotic studies investigate the science of sign and symbols who significantly are involved in a communication process. Linguistic and non-linguistic signs are also explored in semiotic analysis (Caesar \& Michael, 1999).

Ferdinand de Saussure's dualistic notion of signs, comprising of layers of meaning, have been applied for the analysis of cartoon published in daily Dawn. Two forms of meaning are derived from any text: the signifier (the explicit meaning a text is conveying) and signified (the mental concept or meaning derived from the text). Signified meaning cannot necessarily be the same for all people depending on the culture, values, ethics and social system. However, signifier meanings remain same for all the people, as these are the clear, obvious or dictionary meaning of the text. The combination of signified and signifier is formed into an empirical object, called 'sign'. Sign is the representation of mental and explicit meaning of a text (Saussure, 1983).

\section{Material and Methods}

To observe the Pakistani top English newspaper's editorial coverage towards sensitization of catastrophe issue i.e. record breaking rains, the researcher reviewed 
issues of Dawn from August 01 to September 05, 2020 and selected the editorial published on August 29, 2020 along with cartoon of September 02, 2020 for the critical discourse analysis and semiotic analysis respectively.

For the semiotic analysis of the selected cartoon, first of all denotation and connotation was given, which was followed by Barthes (1972) Myth Approach to explain the selected cartoon of daily Dawn. Later, Saussure (1983) approach of signifier and signified was applied to discuss explicit and implicit meanings as reflected by the cartoon. Pierce's Sign Theory (1986) approach was used to analyze the accumulated meanings reflecting both the dictionary meaning and the perceived meanings of the message in the form the selected cartoon. Thus, Pierce' approach was applied to interpret the sings depicted in the subject.

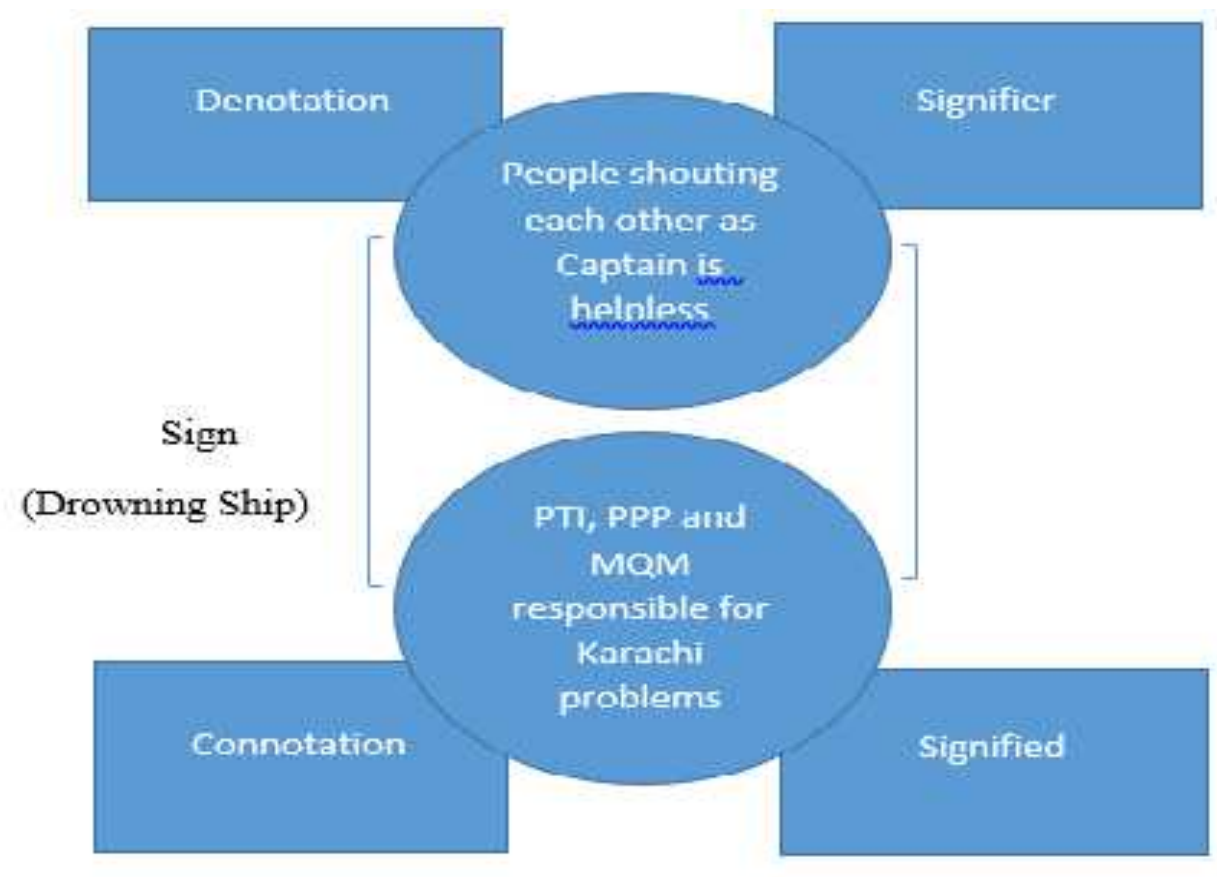

Fig. 1: Uawn Cartoon on Karachı record breakıng cartoon Semiotic Analysis Mode1

Additionally, Fairclough (1995) method of the Critical Discourse Analysis was applied on the Dawn Editorial dated August 29, 2020 depicting the plight of Karachi. Separate analysis of the headline, opening paragraph and all paragraphs was given, besides focusing on the order of the discourse and the selection of vocabulary, grammar and sentence structure using the sentence connectors.

\section{Results and Discussion}

Semiotic Analysis of cartoon published on September 02, 2020 in daily Dawn 


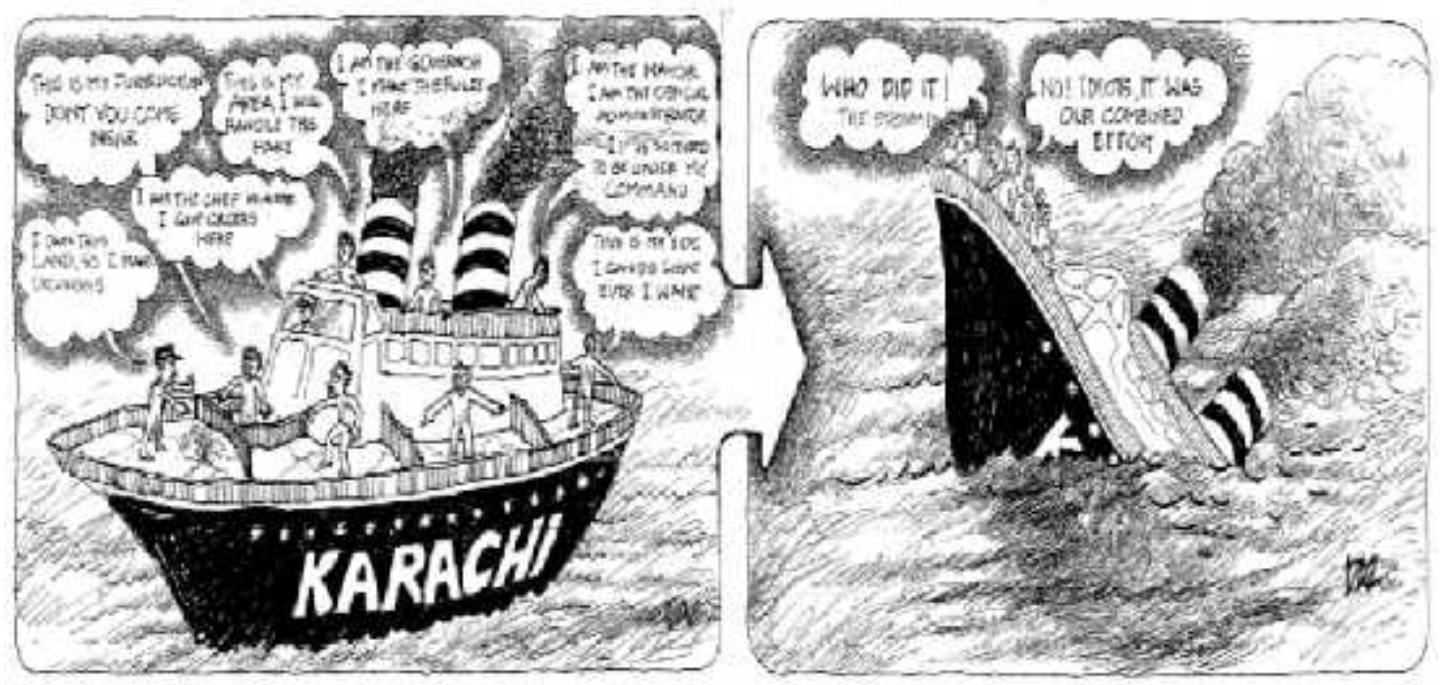

Fig. 2. Daily Dawn Cartoon on Heavy Rains in Karachi

\section{Denotation}

The cartoon is depicting the image of a ship tagged "Karachi". Some people are standing on the ship claiming many statements. In the left pan of the image, it seems ship has some fault in the engine due to storm in the water and huge smoke is coming out from the chimneys, people are blaming each other. While, in the right pan of the image, ship drowned in the sea and people are considering themselves liable for this disaster.

\section{Connotation}

MQM: As shown in the cartoon, on the ship one man (The Mayor) of Karachi is saying, 'I' $\mathrm{m}$ the mayor, I am the officer administrator... be under my command' made rules here'

PTI: Governor of Karachi Imran Ismail is shouting 'I am the governor I

PPP: A man representing PPP claiming, 'this is my jurisdiction, don't come near to me'

One man standing behind the captain saying 'this is my area; I will handle this part. (Karachi).

Every person on the boat is claiming the authority and ownership on the ship

The cartoon image connotes that many people are giving commands to the captain of the ship. Everyone has his own agenda and goals actually misleading the whole Karachi ship resultantly the ship is drowned. 
The political parties are distorting city Karachi, every political party is presenting its own statement and monetary benefits indifferent to the Karachi's destruction. PTI with a 'change' slogan came in governance but practically performed zero. PPP as provincial government just focused on the high-rise construction projects of doubtful nature and played role as barrier in the way of devolution of power towards local government. MQM in terms of local government failed to develop the city rather developing themselves.

\section{Applying Barthes Myth Approach}

The myth behind is the collective control of three political parties in governing Karachi. Mayor of Karachi is from MQM, governor is from federal government (PTI), and provincial government is of PPP. Therefore, the political scenario of Karachi is actually the cocktail of PTI, PPP and MQM, which has increased the sufferings, and distress of Karachi. No political party is developing the city rather all are minting millions and billions of funds for self-enrichment. Myth behind the image is that Karachi has struck between three political parties, who are fighting and blaming against each other and these parties started no practical development work in Karachi. These parties are actually responsible for the destruction of financial hub of Pakistan. The collective poor governance of the said three political parties is behind the current poor condition such a populous city.

\section{Applying Saussure Approach}

- Signifier: the explicit meaning/vocabulary meaning

- Signified: the derived/conceptual meaning from the image

Signifier: 'Signifier' is the situation where ship with word written "Karachi" is drowning. People on the ship are commenting and thinking differently and tension is prevailing in themselves. Dark black color smoke is emitting from chimneys of the ship showing that something technical happened to the ship named "Karachi". The ship is sinking in next phase shown in the cartoon and the people gathered on one edge of the ship, are crying that this happened because of sea storm but they themselves negate that the reason of this disaster is not storm but their combined efforts, which they have done in their lives.

Signified: The mental concept derived from the cartoon is that Karachi is drowning because of the poor governance, bottomless greed of politicians, and lack of decentralization of powers to local governments etc. one caption on the right side of cartoon shows that Karachi people are responsible for themselves for elected such a corrupt, dishonest politician who are just minting the money for self-enrichment not for the sake of general public. 


\section{Applying Peirce SignApproach}

The combination of Signified and Signifier is 'sign'. Sign in this cartoon is the drowning image of Karachi shown in the form of Ship.

Why "drowning ship" taken by the cartoonist to portray poor condition of Karachi?

The reason why cartoonist has taken specially "ship" to demonstrate Karachi poor condition can be interpreted in following two ways:

1. The cartoon published on September 02, 2020; heavy rains inflicted on Karachi just like the sins and blunders in previous week of the publication of cartoon. Three days of severe rainstorm became the cause of hundreds of citizens. This disastrous downpour shattered the 89-year record causing flooded homes and business, non-functionality of all business sectors, electricity shutdown and death rates etc. so, keeping in the view this background, cartoonist's ship in the cartoon well signified the current scenario of Karachi situation after torrential rainfalls. "Ship" well signified the concept of rainstorm and disaster in Karachi.

2. One another relational concept: Karachi is seaside city so to attribute the disaster of Karachi; Ship can be the best sign/symbol.

The association of these general ideas can interpret "ship" as the best sign for the situation drawn. Saussure has stressed on symbolic sign rather than linguistic signs rather, Peirce has given status to the language based signs and symbols. 
Critical Discourse Analysis of Dawn Editorial August 29, 2020

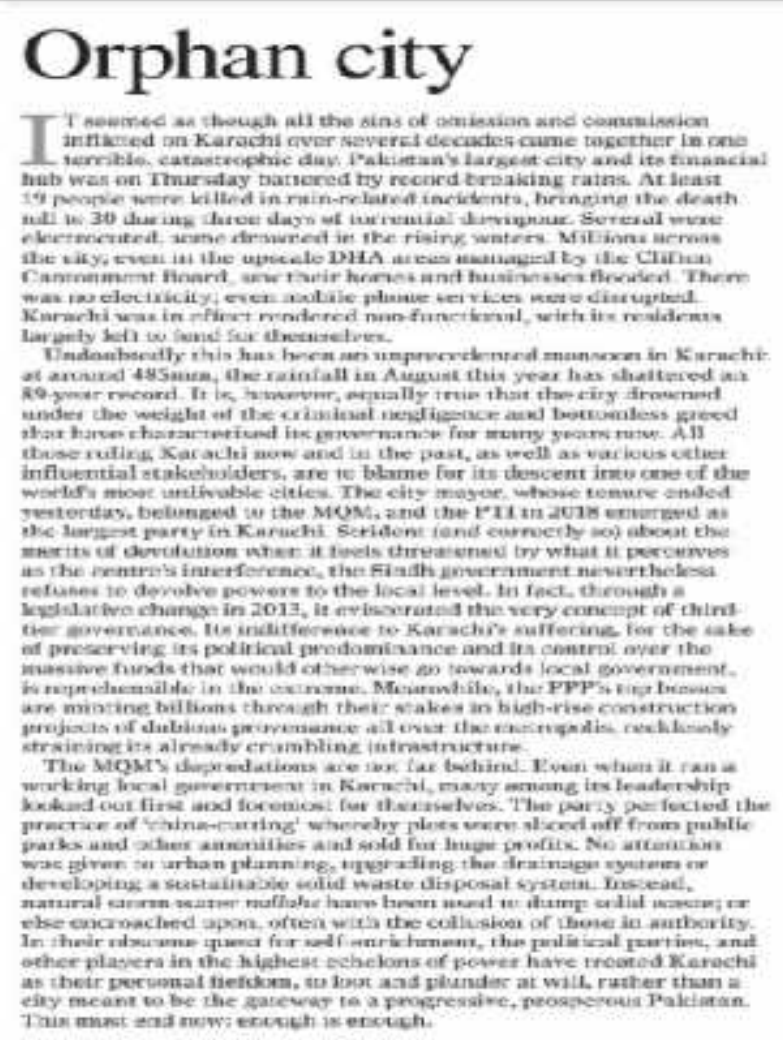

\section{Headline: Orphan City}

The headline of editorial "Orphan City" depicts that something very vulnerable about city is going to be discussed. 'Deprived', 'helpless; or 'incapacitated' are also the words, could be used instead of 'orphan'. However, the selection of word 'orphan' conveys a huge message to the reader about a city with helplessness, vulnerability, depravedness and dependence on some outer forces. On the semantic analysis, headline 'Orphan city' delivers the meaning and factuality about the city, which has no 'say' and is totally helpless.

First paragraph gives a clear picture about the extremely worst condition of city Karachi. 'Orphan city' is labelled, in the editorial, about the Karachi city, which was in flood due to heavy rains in the whole week. Word 'Orphan' is used to express high level of miserable, wretched and sad condition of the city. 'Sins' in the first para is used to express the results of Karachi omission and commission in the shape of catastrophic trouble. In the next sentence editors informed about the fiscal and economic importance of Karachi city which was watered in the rains. Financial hub of Pakistan was helpless and just like orphan city when 30 people were killed and some electrocuted. 'Killed' and 'electrocuted' are the vocabulary used to stress on deaths in Karachi. The city submerged into water making no differentiation to DHA area or Clifton Cantonment Board. Under the umbrella of 'Subtle ordering and 
hierarchization of voices' the researcher observed multiple works like catastrophic, torrential downpour, electrocuted, record breaking rains and drowned in the rising water, to give focus on the poor condition of Karachi in heavy rains.

In second paragraph the starting line was to inform readers about unprecedented rain in Karachi 'ordering of the voice' made by using 'however' soon after telling record-breaking rain falls. Editors equally put liable the poor governance and weak position of rulers. 'Criminal negligence, bottomless greed are the vocabulary words used to stress the government incapability. Editor has demystified the worst condition of Karachi by tagging ruling governance and other stakeholders especially through the selection of phrase "now and in the past". By this phrase, the light is thrown on the ruthless condition of city from past many years. If we observe the analysis of vocabulary, 'unlivable city' the term used for Karachi city. Sociopolitical relation of Karachi city's vulnerable condition is sketched by highlighting PTI emergence and city mayor whose tenure ended last day. 'Textual analysis' of the middle of second paragraph of this editorial reveals that along with the rainy and flooded condition of Karachi, editor also super stressed his claim by connecting the all the political stakeholder in line with mismanagement and corruption. MQM as local government, PTI as federal government and PPP as provincial government, are giving a picture of mess and disorder in Karachi. 'Refusal of Devolution of power by PPP" is the way editor consumed and produced the text to pin point the reasons behind the bad condition of Karachi. Situational context has created by the editor by underlying PPP political prominence and control over massive funds by not devolving powers to local levels.

Here 'representing discourse' is the worst condition of Karachi and 'represented discourse' is 'poor governance, lack of devolution of power to local levels and political prominence behind the poor condition actually causing to the city. In the last ten lines of second paragraph of editorial, editor held responsible to the PPP government over the 'Orphan City'. PTI government discussed in only one line and the writer discussed MQM in three lines. The second para was actually about the political background of the city and socio-political analysis is given here.

The third and the last paragraph, MQM leadership performance 'just for themselves' but 'not for the city' is discussed. To authenticate this perception, editor has given example of "china cutting". More space of last para is given to MQM negligence in development works of city. 'Instead' is the sentence connector to mark the ordering of voices. The extreme negative performance of MQM was expressed by using words like no urban development, poor drainage system etc. 'Selfenrichment', 'huge profits', 'bottom less greed' and 'amenities' are vocabulary words used as substitutes for governments' corruption and negligence. Aggression of the writer on the miserable condition is shown by his selection of words like: 'loot', 'plunder at will' used for the political leaders and other players who used Karachi as their personal domain. 


\section{Analysis and presentation of Narrative}

First, the editor initially narrated the story and afterwards the actual terrible condition of the city after rainfalls. Ordered series of rain events, deaths, torrential downpour, flooded homes and businesses were the facet of a narrative.

The function of language seems prominent, as the editor has presented the story explicitly. Socio-political discourse words, like criminal negligence, bottomless greed are the vocabulary used pointing the worst condition of Karachi's political stakeholders who actually should make the city prosperous and progressive.

In the last lines for Karachi, to be an ideal city, 'prosperous' and 'progressive' are the two synonyms used. Editors' disappointment, distress and aggression is observed by a powerful phrase "enough is enough".

Table 1

Presuppositions of the Selected Editorial Discourse

Clauses and Sentences taken from Presuppositions

original script of editorial

There was no electricity: even mobile Presupposition is that before rains service. Karachi was enjoying all the facilities. City was in peace before rain-related incidents. Before the flood crises and torrential rains, Karachi was in full functional condition, no one had their homes and business flooded and residents were in better condition. Rains became the cause of Karachi's terrible condition.

The Sindh government nevertheless Presupposes that Sindh government's refuses to devolve powers to the local level greediness in the way of devolution of power is responsible for such a destruction in Karachi.

All those ruling Karachi now and in the Presupposes that Karachi is unfortunate past, as well as various other influential in getting any honest and fair stakeholders, are to blame for its descent government from past many years. into one of the world's most unlivable city,

This must end now: enough is enough. Presupposes that even after the huge disaster of the most populous city, no political party is paying attention for the development of Karachi. Presupposes that there is actually no ending in terms of corruption, greediness, self-enrichment of political parties. 
Most Unlivable city

Presupposes that Karachi was livable before corrupt and dishonest governments came into rule from last many years

The binary opposite in the editorial were

\begin{tabular}{ll}
\hline Omission & Commission \\
\hline Now & Past \\
\hline Government & opposition
\end{tabular}

The editor could have ending of the editorial the phrase progressive, prosperous Pakistan, which is the second last line of editorial however, selection of editorial ending on "enough is enough" depicts the real failure and disappointment for city Karachi in the eyes of editor.

Equity and balance: The editor has fully justified pointing the names of relevant authorities responsible for broken Karachi in monsoon rains. Equity and balance has been maintained by mentioning MQM, PPP and PTI equally liable to worst flood disaster in Karachi.

\section{What is excluded in the Editorial?}

National Disaster Management Authority (NDMA) was totally out of the discussion on the Karachi rainy crises issue. The role of NDMA cannot be overlooked whenever the issue of rains, floods and earthquakes is being discussed. So, according to critical discourse analysis NDMA should also have been part of the discussion.

\section{Conclusion}

The plight of the Karachi has been depicted truly by Daily Dawn editorial and carton. The critical discourse analysis of the editorial and semiotic analysis of the cartoon speak volumes about the administrative state of the affairs of the port city. The study found criminal negligence of the administration and bottomless greed of the politicians fixing responsibility on all three governments i.e. MQM's city district government, PPP led provincial government and the PTI's federal government.

\section{Recommendations}

This study is based on the CDA and semiotic analysis of editorial and cartoon respectively on the issue of the heavy rains in Karachi. Feature studies may focus other administrative affairs including the frequent fire eruption issues, sanitation and issues of the business community and fishermen of the port city. 


\section{References}

Aidoo, K. K. (2005). Topical issues in communication and media research. New York: Nova science publishers inc.

Albright, E.A. \& Crow, D. (2019). Beliefs about climate change in the aftermath of extreme flooding. Climatic Change 155, 1-17 (2019). https://doi.org/10.1007/s10584-019-02461-2

Almost 50 killed in three days of monsoon rain across Pakistan. aljazeera.com. 9 August 2020. Retrieved 28 August 2020 from: https://www.aljazeera.com/news/2020/08/09/almost-50-killed-in-three-days-of-monsoonrain-across-pakistan/

Anderson, A. (1997). Media, culture and the environment. New Brunswick: NJ: Rutgers University Press.

Anderson, A. (2009). Media, politics and climate change: Towards a new research agenda. Sociology Compass, 3(2), 166-182

Azmi, N. J. et at. (2015). Media Portrayal on Global Climate Change: An Analysis of Malaysian Mainstream Newspapers. Studies in Media and Communication. DOI: https://doi.org/10.11114/smc.v3i1.815

Boykoff, M., Roberts, J. (2007). Media coverage of climate change: current trends, strengths, weaknesses. United Nations Development Programme $\sim$ Human Development Report 2007 background paper FINAL VERSION 2007

Caesar, Michael. (1999). Umberto Eco: Philosophy, Semiotics, and the Work of Fiction. Wiley-Blackwell. p. 55. ISBN 978-0-7456-0850-1.

Chiaoning, S. (2020). Feeling the catastrophe: the interplay between emotional storytelling and journalistic authority in the televisual construction of natural disasters, Asian Journal of Communication, 30:5, 363385, DOI: $10.1080 / 01292986.2020 .1813182$

Dearing, J. \& Rogers, E. (1998). Agenda-setting research: Where has it been, where is it going, Communication Yearbook, 11,555-594.

Disaster Management in Sindh with historical perspective. Provincial Disaster Management Authority web page. Retrieved on October 05, 2020 from:http://www.pdma.gos.pk/new/aboutus/history.php

Fairclough, Norman. (1995). Critical Discourse Analysis: The Critical Study of Language. Longman. ISBN 978-0582219847. 
Hoppe, A. D., \&Wolling, J. (2011). Climate change and media usage: Effects on problem awareness and behavioral intentions. International Communication Gazette,73(1-2), 45-63.

In pictures: Torrential rain floods Karachi, shatters records. dawn.com. 27 August 2020.

Kamboh, S. A., \&Yousaf, M. (2019). Human development and advocacy journalism: Analysis of low editorial coverage of human development issues in Pakistan. Development Policy Review, Accepted Author Manuscript. doi: 10.1111/dpr.1244

Lahsen, M., Couto, G.d. \&Lorenzoni, I. (2020). When climate change is not blamed: the politics of disaster attribution in international perspective. Climatic Change 158, 213-233 (2020). https:/ / doi.org/10.1007/s10584-019-02642-z

Pakistan: Karachi experiences worst floods in almost a century, dozens dead. (2020, August 28). Deutsche Welle (www.dw.com).

Pérez-Lugo, Marla. (2001). The Mass Media and Disaster Awareness in Puerto Rico: A Case Study of the Floods in Barrio Tortugo. Organization \& Environment. 14. 55-73. 10.1177/1086026601141003.

Riboldi, et al. (2015). The role of the media in flood management. Retrieved October 05, 2020 from:

https://www.floodmanagement.info/publications/tools/Tool_22_The_Role_of _the_Media_in_Flood_Management.pdf

Saussure, Ferdinand de. (1916). Course in General Linguistics, trans. Roy Harris (La Salle, Ill.: Open Court, 1983). Retrieved October 05, 2020 from: http://cahiers.kingston.ac.uk/concepts/linguistics.html

Short, T. (2007). Peirce's Theory of Signs. Cambridge: Cambridge University Press. doi:10.1017/CBO9780511498350

Siyao, P. \&Sife, A., (2020). Prominence of occurrence accorded to climate change information in Tanzanian newspapers. Alexandria: The Journal of National and International Library and Information Issues. Mzumbe University. Retrieved from: https://doi.org/10.1177/0955749020950608

Van Dijk (1985). Discourse and Communication: New Approaches to the Analysis of Mass Media Discourse and Communication (re-printed 2011). Berlin (Germany): De Gruyter 